\title{
Suspension of Execution Rights of Warranties by Separate Creditors in Climate
}

\author{
Suratman $^{1}$ and Nurjani Jalal ${ }^{2}$ \\ \{suratmanshmh@gmail.com ${ }^{1}$, nurjanijalal@gmail.com² \\ Faculty of Law, Islamic University of Malang, Indonesia ${ }^{1}$, Faculty of Law, Gajah Mada \\ University, Indonesia ${ }^{2}$
}

\begin{abstract}
The purpose of this study is to analyze the reasons for the deferment period (stay) of the right to execute collateral against separatist creditors in bankruptcy, and the consequences of a stay period for the execution rights of separatist creditors in bankruptcy based on Law No. Postponement of Debt Payment Obligations. The research method used is juridical normative, with a statute approach and a conceptual approach. Sources of legal materials used consist of primary legal materials, secondary legal materials, and tertiary legal materials. The analysis used in this study uses the content analysis method. Based on the results of the study, it can be concluded that the reason for the postponement (stay) of the right to execute collateral against separatist creditors in bankruptcy is to prevent fraud in exercising their execution rights which will harm other creditors, especially concurrent creditors whose receivables are not guaranteed by the debtor's property rights. As a result of the existence of a period of suspension (stay) for the execution rights of separatist creditors in bankruptcy, the separated and prioritized position as reflected in Article 55 paragraph (1) of the Bankruptcy Law has changed to a position equivalent to that of a concurrent creditor (Article 56 paragraph (1) The Bankruptcy Law and the loss of execution right for separatist creditors because this right is granted by law to the curator as regulated in (Article 56 paragraph (3) of the Bankruptcy Law). The contribution of research results to scientific development is that it is necessary to strictly regulate the suspension of execution in bankruptcy, so as not to diminish the authority of separatist creditors in exercising their execution rights in bankruptcy and so as not to give the impression of a clash of norms with one another.
\end{abstract}

Keywords: Suspension of Execution Rights; Separatist Creditors; Bankruptcy

\section{Introduction}

Bankruptcy is a condition in which the debtor is unable to pay the debts of his creditors 1. The decision to declare bankruptcy against the debtor results in the law of all the assets of the bankrupt debtor in general confiscation by the curator. The task of the curator, in this case, is to manage and settle the assets of the bankrupt debtor to settle all debtors' liabilities towards creditors by the principles contained in the bankruptcy law. Three main principles in settling debtors 'debts against creditors include the crematorium parity principle, which is the principle that determines that all creditors have the same rights to all debtors' assets2, besides that, there is also the pari pasu pro rata parte principle that the debtor's assets are a joint guarantee for creditors and distribution of debtors' assets to pay off their debts to creditors in a more equitable manner by their proportions (pond-pond gewijs) and not because they are equal3. 
Furthermore, the two principles above are complemented by the principle of structured creditors which provides various classifications -types of creditors according to their position because it is unfair if the concurrent creditor is equal to the creditor holding the guaranteed right and the creditor holding the preferential rights granted by law. This injustice is given a way out by the existence of the structured creditor's principle, namely the principle that classifies and classifies various types of creditors according to their respective classes, namely separatist creditors, preferred creditors, and concurrent creditors4.

The principle of structured creditors is very important for separatist creditors, both in guarantee law and bankruptcy law. In the law, the separatist creditor who is creditor who holds the property security right has the right to execute the collateral if the debtor in default or the debtor is declared bankrupt. The existence of a guarantee institution is recognized in bankruptcy law to provide certainty and protection for creditors who hold the right to guarantee material to execute collateral if the debtor is declared bankrupt by the court.

The right to execute a separatist creditor who holds the right to material security has been guaranteed by the bankrupt debtor for his obligations as stipulated in Article 55 paragraph (1) of the Bankruptcy Law. In addition to these provisions, the rights of execution of separatist creditors are regulated in the material security law, including as stipulated in Article 21 of Law Number 4 of 1996 concerning Mortgage Rights to Land and Land-related Objects (hereinafter abbreviated to the Mortgage Rights Law), stating that "If the guarantor of the mortgage is declared bankrupt, the holder of the security right is still authorized to exercise all the rights he has obtained according to the provisions of this law." Furthermore, the right to execute separatist creditors who hold the right to fiduciary security is also regulated in Article 27 of Law Number 42 of 1999 concerning Fiduciary Security (hereinafter abbreviated as the Fiduciary Security Act), which states that "the first rights of fiduciary recipients are not abolished due to bankruptcy and/or fiduciary giver liquidation".

Provisions regarding the execution rights of the creditor who holds the right to guarantee material when the debtor goes bankrupt in the guarantee law as stipulated in Article 21 of the Mortgage Law and Article 27 of the Fiduciary Security Law are shown to further strengthen the position of priority or priority to creditors who hold mortgage rights or rights. fiduciary security, furthermore priority position by creditors holding pledge and mortgage rights is also regulated in Article 1134 of the Civil Code which states that "liens and mortgages are higher than special privileges except in cases whereby law it is determined otherwise".

Thus, the priority position of the separatist creditor in exercising the right of execution of the object of security of the bankrupt debtor's property that has been guaranteed by the bankrupt debtor to settle all of its obligations is regulated in article 55 paragraph (1) of the Bankruptcy Law which states that the provisions as referred to in Article 56, Article 57, and Article 58, every creditor holding a pledge, fiduciary, mortgage, mortgage, or other collateral right on property, can exercise his rights as if there was no bankruptcy".

However, the exercise of the right of execution by separatist creditors as stipulated in Article 55 paragraph (1) of the Bankruptcy Law is inconsistent with Article 56 paragraph (1) of the Bankruptcy Law because the exercise of the right of execution by separatist creditors in the bankruptcy process must be suspended for 90 days from the pronouncement of the decision to declare bankruptcy which results in the separatist creditors during the suspension period having no right to execute the collateral.

Based on the description above, the authors are interested in conducting research, by raising the following issues: (1) Why is there a period of deferment (stay) for the right to execute collateral against separatist creditors in bankruptcy and (2) whether the legal 
consequence is that there is a suspension period (stay) for the right of execution separatist creditors in a bankruptcy?

\section{Research Method}

\subsection{Type of Research}

This type of research includes descriptive research. Descriptive research is research that aims to describe something in a certain area and at a certain time. Usually in this study, the researcher has obtained/has an overview in the form of preliminary data about the problem to be studied5. In this study, it is hoped that it can provide a clear and complete explanation that describes the execution rights of separatist creditors from the perspective of bankruptcy law.

\subsection{Research Approach}

In normative juridical research, several approaches aim to obtain information from various aspects to answer legal issues, one of the approaches used in this research is the statute approach and the conceptual approach. A statute approach is an approach that is carried out by examining all laws and regulations related to legal issues that are being handled by studying whether there is consistency and suitability between one law and another or between regulations and laws. invitations6. While the conceptual approach is an approach that departs from views and doctrines that develop in legal science which will then be studied by researchers to find ideas that give birth to legal notions, legal concepts, and legal principles relevant to the issues at hand 7 .

\subsection{Legal Material Sources}

In normative legal research, sources of legal materials can be primary legal materials, secondary legal materials, tertiary legal materials:

a. Primary legal materials, namely materials that have strength binding law9. In research, the primary legal materials are laws and regulations are used, including Civil Code (BW), Law Number 37 of 2004 concerning Bankruptcy and Postponement of Debt Payment Obligations, Law Number 4 of 1996 concerning Mortgage Rights, and Law Number 42 of 1999 concerning Fiduciary Guarantee.

b. Secondary legal materials are materials that are closely related to primary legal materials and can help analyze and understand primary legal materials 10.

c. This legal material used in research is in the form of books or literature on law, and other forms of legal publications 11 . Tertiary legal materials, namely materials that provide information about primary and secondary legal materials. In this study, a legal dictionary is used

\subsection{Legal Material Collection Techniques}

In this research the methods or techniques used to collect data are as follows:

a. Selecting and sorting legal materials related to research, namely primary legal materials are carried out by checking the prevailing laws and regulations in the form of those related to bankruptcy law and guarantee law, secondary legal materials are carried out by selecting and sorting books or references or literature discusses bankruptcy, guarantees, creditors and execution, in addition to tertiary legal materials it is done by selecting the 
meaning of the words needed and to complete primary and secondary legal materials by using a legal dictionary.

b. Studying and examining legal materials, namely if after obtaining legal materials by selecting and sorting primary legal materials, secondary legal materials, and tertiary legal materials related to research, then it is continued by studying and examining the substance, material, meaning of these legal materials.

c. Furthermore, the legal materials that have been studied and reviewed are presented in the form of descriptions that are systematically structured, namely relating to one another the primary materials with secondary legal materials as well as tertiary legal materials that have been obtained and can then be put together clearly. and complement each other according to research needs.

\subsection{Legal Material Analysis}

Based on the legal material obtained from further research analyzed. The analysis used in this study uses the content analysis method which is based on normative analysis, which is a way to find, identify, and analyze the content, meaning, or substance of legal materials based on legal norms or legal principles related to the subject matter, and then a conclusion is drawn.

\section{Discussion}

\subsection{There is a Stay Period of Execution Right of Collateral for Separatist Creditors in Bankruptcy}

\section{Separatist Creditor Position}

Munir Fuady stated that separatist creditors are creditors who have material debt guarantees (collateral rights), such as holders of mortgages, mortgages, pawns, fiduciaries, and others (Article 55 paragraph (1) of the Bankruptcy Act). Creditors with guarantees that are not material (such as guarantees including bank guarantees) are not separatist creditors12. So narrowly, creditors holding liens, mortgages, mortgages, and fiduciary rights are separatist creditors. One of the characteristics of the material guarantee is that the creditor holding the property security right has a guaranteed right, namely the right to sell or execute and take the proceeds of the sale first from other creditors as a form of repayment of the debt if the debtor defaults or is declared bankrupt.

The following are separatist creditors who have material security rights who can sell or execute guarantee rights and take the proceeds from the sale even though the debtor is declared bankrupt as follows:

a. The holder of a pledge, pawning is regulated in Article 1150 of the Civil Code to Article 1160 of the Civil Code, and the arrangement for the right to execute a pledge is regulated in Article 1155 of the Civil Code.

b. Holders of mortgage rights, arrangements regarding the execution of mortgages by holders of mortgage rights are regulated in Article 1178 of the Civil Code.

c. Holders of mortgage rights, arrangements regarding the execution of mortgage rights by holders of mortgage rights if the debtor goes bankrupt is regulated in Article 6 in conjunction with Article 21 of the Law on Mortgage Rights 
d. Holders of fiduciary security rights, arrangements regarding the execution of fiduciary guarantees by holders of fiduciary security rights if a debtor is bankrupt are regulated in Article 15 paragraph (3) and Article 27 paragraph (3) of the Fiduciary Guarantee Law.

The existence of a guaranteed right attached to the separatist creditor as the creditor holding the right to guarantee the material provides a valid reason for repayment of the concurrent creditor as stipulated in Article 1132 of the Civil Code as follows "the material becomes a joint guarantee for all those who deposit on it, income the sale of the goods shall be divided according to the balance, namely according to the size of the respective receivables, unless there are valid reasons for prioritization among the debtors.

The provisions above clearly regulate the existence of a creditor who can take the payment of the proceeds from his sale first from another creditor because the creditor has valid reasons to take precedence. Furthermore, the reason for creditors who have precedence over concurrent creditors can only be obtained from either the creditor because the privilege rights or creditors who have property security rights as confirmed in Article 1133 of the Civil Code "the right to take precedence among persons owed is issued from privileges, from the pledge. and the mortgage".

Based on the provisions of Article 1132 of the Civil Code and Article 1133 of the Civil Code, it can be understood that the precedence for separatist creditors in the guarantee law of these provisions aims to further strengthen the prioritized position of concurrent creditors. Even a separatist creditor who holds property security rights (pledge, mortgage, mortgage, and fiduciary security) has a higher position than creditors who because of the nature of the debt (preferred creditors), unless the law stipulates otherwise as stated in Article 1134 paragraph (2) Civil Code which states "Pawning and mortgages are higher than privileges, except in cases whereby law it is determined otherwise".

The existence of the provisions above which give priority to creditors who hold material security rights shows that the separatist creditor has a priority position from the concurrent creditor and is higher than the creditor due to the nature of the debt (the preferred creditor) unless the law stipulates otherwise (Article 1134 Civil Code), this clarifies that if the debtor is in default and/or the debtor is declared bankrupt, the separatist creditor as the creditor holding the property guarantee rights can exercise his right by selling and taking the proceeds from the sale first from other creditors.

Apart from the guarantee law, the priority position of the creditor is separatist reflected in the bankruptcy law as stated in Article 55 paragraph (1) of the Bankruptcy Law as follows. "With due observance of the provisions referred to in Article 56, Article 57, and Article 58, each creditor holder liens, fiduciary security, mortgage, and mortgages or other collateral rights over property, can exercise their rights as if there was no bankruptcy ". With these provisions, it gives priority to separatist creditors who hold liens, mortgages, mortgages, and fiduciary security, namely that the existence of a decision to declare bankruptcy does not affect the creditor holding material security rights to exercise his right of execution on the pledged property.

Guarantee law recognizes the term "separatist creditor", which is said to be a separatist with the connotation of "separation" because the creditor's position is indeed separated from other creditors, in the sense that the creditor can sell himself and collect the proceeds from the sale which are separate from the bankruptcy assets in general13. Article 1132 of the Civil Code, creditors who hold material security rights are separated from concurrent creditors in terms of taking their receivables in full because the creditor holding the guarantee rights can sell and take precedence in taking the proceeds from the sale from the concurrent creditor. 
Furthermore, it is regulated in Article 1134 of the Civil Code which provides separation between creditors who hold property security rights and creditors who hold the same privileged rights having priority credit but the position of the creditor who holds the property security right is higher than the creditor who holds the privilege unless the statute specifies otherwise.

Thus, Article 1132 of the Civil Code and Article 1134 of the Civil Code not only give priority to separatist creditors as property security rights holders but also solely provide rights that are separated from other creditors, so that the separatist creditor not only has a prioritized position as well as being separated from the creditor other. In bankruptcy law, starting from the principle of structured creditors, which began to be applied to classify various creditors when the decision on the bankruptcy declaration was passed on to the debtor, the creditor who holds the property security rights is classified as a separatist creditor to be separated from other creditors, namely preferred creditors and concurrent creditors. Separatist creditors who have a separate position and rights are contained in Article 55 paragraph (1) of the Bankruptcy Law as follows. dependents, and mortgages or other collateral rights on the property, can exercise their rights as if there was no bankruptcy".

Regarding the provisions of the article above, what is meant by being able to exercise his rights by a separatist creditor is to execute the right to guarantee material, namely the right to sell objects that are guaranteed as collateral for repayment of debtors' debts and priority rights, namely the right to take precedence in making repayment of the proceeds from the sale of goods that are guaranteed from the creditor. other. Thus, exercising all the rights obtained by a separatist creditor by selling and taking the proceeds from his sale of the guaranteed goods as if there was no bankruptcy, is a separate right for preferred creditors and concurrent creditors, so that in this case the separatist creditor has a separate position. from other creditors.

Based on the description above, creditors who have priority and segregated positions in exercising their rights of execution are regulated in the guarantee law and are also regulated in Article 55 paragraph (1) of the Bankruptcy Law. However, the implementation of Article 55 paragraph (1) of the Bankruptcy Law shall still observe the provisions of Article 56 paragraph (1) of the Bankruptcy Law which states "the creditors' exercise rights as referred to in Article 55 paragraph (1) and the rights of third parties to sue their assets. is under the control of the bankrupt debtor or curator, it is suspended for not more than 90 (ninety) days from the date the bankruptcy decision is pronounced".

The understanding of Article 56 paragraph (1) of the Bankruptcy Law above has put the separatist creditor position on hold for 90 (ninety) days within that period, the position of the separatist creditor is no longer prioritized and separated, so that it is equal to other creditors, because of the separatist creditor's authority to execute objects that are guaranteed to be postponed or postponed for 90 (ninety) days from the time the bankruptcy decision is pronounced14. The right to execute separatist creditors as stipulated in Article 55 paragraph (1) of the Bankruptcy Law will only begin to be implemented after the suspension period ends and the separatist creditor, in this case, has a priority and is separated.

\section{Separatist Creditors' Rights}

The right of the separatist creditor holder of the material security right to execute the object guaranteed in bankruptcy has been granted by the bankruptcy law as stipulated in Article 55 paragraph (1) of the Bankruptcy Law which states that "With due observance of the provisions referred to in Article 56, Article 57 and Article 58, every creditor holding a pledge, fiduciary security, mortgage, and mortgage or other collateral rights on the property, can exercise his rights as if there was no bankruptcy". 
The above provisions are clear that the bankruptcy law gives authority to separatist creditors to exercise their execution rights in bankruptcy by taking into account the provisions of Article 56 paragraph (1) of the Bankruptcy Law, namely suspension of execution. The authority of the separatist creditor is the holder of the property security right, namely in the period before the bankruptcy decision, after the end of the stay (suspension) and 2 (two) months after the insolvency 15.

The authority to execute by a separatist creditor who holds a property security right can be exercised before the collapse of bankruptcy if the debtor has defaulted or has broken promises as regulated in the following conditions:

a. Pledge, the authority to execute the pledge is regulated in Article 1155 of the Civil Code which states that if the parties have not agreed otherwise, then the debtor is entitled if the debtor or the pledge provider is the default, after a predetermined grace period, or if not already determined. a grace period, after which a warning is made to pay, orders to sell the pledged goods in public according to local customs and on customary terms, to take full payment of the amount due, along with interest and fees from the sales revenue. 2)

b. Mortgages, the authority to execute mortgages is regulated in Article 1178 paragraph (2) of the Civil Code which states that however it is permissible for the first mortgage debtor to, at the time the mortgage is granted, expressly ask for an agreement that, if the principal is not paid properly, or if the interest is if the debt is not paid, he will have the power to sell the parcels which are publicly bound, to collect the principal, as well as interest and expenses, from the sales revenue. This promise must be made in the manner provided for in Article 1211.

c. Mortgage rights, the authority to execute mortgage rights are stipulated in Article 6 of the Mortgage Rights Law which states, if the debtor fails to promise, the holder of the first security right has the right to sell the object of the mortgage right at his power through a public auction and collect the receivables from the sale proceeds. the.

d. Fiduciary security, the authority to execute fiduciary guarantees is regulated in Article 15 paragraph (3) of the Fiduciary Guarantee Law which states, if a debtor fails to promise, the fiduciary recipient has the right to sell objects that are the object of fiduciary security over his power.

The authority of the separatist creditors during the postponement period is because based on Article 56 paragraph (1) of the Bankruptcy Law, from the time the decision to declare bankruptcy is up to 90 (ninety) days, the right to execute collateral is suspended so that the authority to execute the separatist creditor during this period of the curator. Thus, the authority of a separatist creditor is the right to execute collateral in bankruptcy and is exercised after the postponement period ends, which is 90 (ninety) days or sooner than that with the determination of insolvency (Article 57 paragraph (1) of the Bankruptcy Law).

Furthermore, the regulation regarding the authority of separatist creditors in selling collateral for two months after the insolvency is regulated in Article 59 paragraph (1) of the Bankruptcy Law "with due observance of the provisions of Article 56 and Article 58 of the holding creditor as referred to in Article 55 paragraph (1). Must exercise the said rights within 2 (two) months at the latest, after the start of the situation as referred to in Article 178 paragraph (1). " This provision makes it clear that after the determination of insolvency, the rights of the separatist creditors can exercise their rights within a maximum period of 2 (two) months.

What is meant by exercising his rights is that the creditor has started exercising his rights16. If during the period given after the insolvency has begun, the separatist creditor who 
holds the security right does not exercise his execution rights, then the separatist creditor does not have the right to execute the guaranteed object because the authority has been taken away. transfer by the curator to sell objects that are burdened with collateral rights without prejudice to the rights of the creditor of the right holder on the sale of the collateral (Article 59 paragraph (2) of the Bankruptcy Law)17.

\section{Staying of Collateral Objects Execution Rights Against Separatist Creditors in Bankruptcy}

This period of deferral of the rights of separatist creditors is also known as a stay or standard period. According to Fuady, a stay is a cool-down period or legal moratorium. From the perspective of the bankruptcy law, the stay period is a postponement of execution of bankruptcy assets that occurs for the sake of law without the need to be asked by the curator18. What is meant by the suspension of execution of debt guarantees in bankruptcy law is certain periods even though the right to execute the debt guarantee is in the hands of the creditor. the separatists cannot execute him.

So the right to execute separatist creditors is in a "waiting period" for a certain period, where after the waiting period ends, it is only justified to execute the debt guarantee, this is as regulated in Article 56 paragraph (1) of the Bankruptcy Law which states "rights execution of the debtor as referred to in Article 55 paragraph (1) and the right of the third party to claim his assets which are under the control of the bankrupt debtor or curator, are postponed for a maximum period of 90 (ninety) days from the date the bankruptcy verdict is pronounced". The postponement of execution in the provisions above is intended as a period of silence or a period in which there are no claims to pay off debts or exercise the fulfillment of the rights of creditors, either based on a court decision or based on the title of the executioner.

Also, during the suspension period, separatist creditors do not have separate and prioritized rights as regulated in the guarantee law20. According to Hadi Subhan, the philosophy of the provisions of Article 56 paragraph (1) of the Bankruptcy Law is the creditor who holds the right to guarantee the material executing the collateral to collect the debt as a form of repayment of the bankruptcy debtor's debt, if there is a residual value from the result of the execution or sale, then in the context of bankruptcy the residual value of the execution results must be included in the bankruptcy estate/bankruptcy bill.

But in practice often, a separatist creditor who holds the right to guarantee the material for the sake of fulfilling his interests is to execute or sell the collateral at a fast selling price or a below-market price that is equivalent to the receivable, in which case the guaranteed object should get a fair price from a below-market price the result of the execution of the collateral object not only pays the receivables against the right holder of the collateral property, but the rest of the payment can be used by the curator to pay other creditors' receivables.

To avoid the actions of creditors who hold the property security rights, in this case, there is an arrangement regarding a postponement period of 90 (ninety), allowing the curator to get a fair price and the best price so that the value of the results of the execution does not only meet the payment of the receivables. Separatist creditors take precedence only, but the residual value from the execution or sale of collateral objects can also meet the settlement of receivables from preferent creditors as well as concrete creditors.

Thus, the authority of separatist creditors in exercising their execution rights is not affected by the bankruptcy as regulated in Article 21 of the Mortgage Rights Law and Article 27 paragraph (3) of the Fiduciary Security Law does not impair the execution rights of creditors who hold liability rights and fiduciary security rights which has been regulated in the guarantee law with the enactment of Article 56 paragraph (1) of the Bankruptcy Law, because 
the purpose of the suspension of separatist creditors is inseparable from the objective of the bankruptcy law itself, namely as a collective proceeding to collect and maximize the liquidation value of bankruptcy assets for distribution to all creditors based on the ranking and nature of the creditors' respective creditors.

Therefore, the stay is enforced to prevent separatist creditors from committing fraud in exercising their execution rights which will harm other creditors, especially concurrent creditors whose receivables are not guaranteed by the debtor's property rights. Furthermore, during the suspension period the curator can carry out his duties optimally by carrying out management, namely inventorying, maintaining, and maintaining so that bankruptcy assets do not decrease in number, value and even increase in number and value.

Bankruptcy by using and executing bankruptcy assets in the form of movable and immovable objects under the control of the curator in the context of the debtor's business continuity by providing reasonable protection for the interests of creditors or third parties. All management of bankruptcy assets carried out by the curator is not only to optimize the bankruptcy assets but also to assist the bankrupt debtor to offer a peace plan to the creditor. If the peace plan is approved by the creditor and approved by the court, it will have important legal consequences, especially for the bankrupt debtor, namely the bankruptcy will end soon, then the bankrupt debtor can be rehabilitated, namely the restoration of the status of the bankrupt debtor to become a legal subject with authority over his assets.

Based on the descriptions above, it can be understood that the suspension in bankruptcy occurs for the sake of law after the decision to declare bankruptcy is pronounced and this suspension intends that the curator only sided with the law which aims to protect all the interests of the parties, even though the separatist creditor has an object that is burdened. with a guarantee that the material will be executed by the curator but still provide reasonable protection to the separatist creditors whose execution rights have been exercised by the curator.

Even then, objects that are encumbered with property security rights can only be used and executed by the curator in the context of the debtor's business continuity which aims to optimize the bankruptcy property, so that the curator can help the debtor to offer conciliation to concurrent creditors. Thus, the curatorial action above is an action that stands above the interests of all parties without any party being harmed. Furthermore, the reasons for the suspension of execution are also contained in the explanation of Article 56 paragraph (1) of the Bankruptcy Law which aims to24:

a. Suspension of execution is intended to increase the likelihood of achieving peace.

b. The postponement of execution is intended to increase the possibility of optimizing bankruptcy assets.

c. Suspension of execution is intended to enable curators to carry out their duties optimally.

Parties who are obliged to be subject to a suspension of execution are those who are stipulated in Article 55 paragraph (1) of the bankruptcy law as follows:

a. Creditors who hold liens

b. Creditors who hold the mortgage rights

c. Creditors who hold mortgage rights

d. Creditors who hold fiduciary rights

e. Creditors who hold other property security rights, for example, advertisement rights holders, ownership retention rights holders, and others. 


\subsection{Legal Consequences of Staying Against the Right to Execute Separatist Creditors in Privileges}

Starting from the result of the postponement period of the execution rights of separatist creditors, namely as read in Article 56 paragraph (1) of the Bankruptcy Law as follows "the right to execute creditors as referred to in Article 55 paragraph (1) and the rights of third parties to claim their assets in control of the bankrupt debtor or curator is suspended for a maximum period of 90 (ninety) days from the date the bankruptcy decision is pronounced".

The provisions above contain the meaning that the period of stay in bankruptcy for the exercise of the rights of execution of a separatist creditor is a period in which for 90 (ninety) days the separatist creditor cannot sell the object that is guaranteed since the decision to declare bankruptcy, because his right of execution is suspended so that during the suspension period The separatist creditor does not have the right to be prioritized and segregated as regulated in Article 55 paragraph (1) of the Bankruptcy Law and the position of the separatist creditor, in this case, becomes equal to other creditors during the suspension period.

In connection with the suspension of the right of execution by the separatist creditor who holds the property security right, the right to execute on bankruptcy assets, including objects that are charged with guarantee rights during the suspension period in bankruptcy, can only be carried out by the curator, this is as regulated in Article 56 paragraph (3) of the Law. -The Bankruptcy Law states that "during the postponement period as referred to in paragraph (1), the curator may use bankruptcy assets in the form of movable objects under the control of the curator in the context of the debtor's business continuity if reasonable protection has been provided for the benefit of the creditor and third party. as referred to in paragraph (1)".

The above provisions are clear that the object subject to guarantee rights is part of the bankruptcy estate which is under the control and management of the curator. In this case, the curator can use and sell objects that have a guarantee right in the context of running a debtor's business that can optimize the bankruptcy's assets, so that the curator's action eliminates the separatist creditor's right to take precedence and separation as regulated in Article 55 paragraph (1) of the Bankruptcy Law.

If the separatist creditor's right to act by the curator is lost, the separatist creditor's right to execute on the object that is subject to the guaranteed right is deemed null and void by providing fair protection to the separatist creditor. Referred to as reasonable protection for separatist creditors, namely the protection that needs to be provided to protect the discontinuation of a separatist creditor because the right of execution has been taken over by the curator.

Based on the elucidation of Article 56 paragraph (3) of the Bankruptcy Law, reasonable protection provided to separatist creditors can be in the form of:

Elucidation of Article 56 paragraph (3) of the bankruptcy law

a. Compensation for impairment of bankruptcy assets;

b. The proceeds from the bankruptcy sale;

c. Substitute material rights;

d. Fair and fair rewards and other cash (guaranteed debit) payments.

Based on the provisions above, due to the postponement period of separatist creditors, namely, the separated and prioritized position as reflected in article 55 paragraph (1) of the Bankruptcy Law has changed to an equal position with concurrent creditors (Article 56 paragraph (1) of the Law Bankruptcy Law) and the loss of execution rights of separatist creditors because this right is granted by law to the authorized curator as regulated in (Article 56 paragraph (3) of the Bankruptcy Act). 
However, changes in position and loss of rights of separatist creditors in exercising their execution rights are not permanent or absolute, because based on Article 57 paragraph (1) of the Bankruptcy Law "the period referred to in Article 56 paragraph (1) of the Bankruptcy Law ends for the sake of law at the time of bankruptcy is terminated sooner or when the state of insolvency as referred to in Article 178 paragraph (1)".

Regarding these provisions, it can be understood that the end of the stay period, namely by law it will end after 90 (ninety) days or sooner because insolvency is determined in bankruptcy, in this case, the separatist creditor who holds the security right can exercise his right of execution. If the object that is guaranteed is guaranteed, unless the object for which the security right is charged has been executed by the curator, then the separatist creditor does not have the right to claim the fulfillment of his / her rights to the object that is subject to the guaranteed right because the curator has provided reasonable protection to the separatist creditor whose collateral has been executed by the curator (Article 56 paragraph (3) of the Bankruptcy Act).

\section{Conclusion}

Based on the description and explanation as described above, it can be concluded that:

a. The reason for the suspension period (stay) of the right to execute collateral against separatist creditors in bankruptcy according to Law Number 37 of 2004 concerning Bankruptcy and Postponement of Debt Payment Obligations, to prevent fraud in exercising his right of execution which will harm other creditors, especially concurrent creditors who the receivables are not guaranteed by the debtor's material rights.

b. As a result of the existence of a period of deferment (stay) on the execution rights of separatist creditors in bankruptcy based on Law Number 37 of 2004 concerning Bankruptcy and Postponement of Debt Payment Obligations, namely the separated and prioritized positions as reflected in Article 55 paragraph (1) of Law The Bankruptcy Law provides a position to change to an equal position with a concurrent creditor (Article 56 paragraph (1) of the Bankruptcy Law provides for the position and loss of the right to execute separatist creditors because these rights are granted by law to the competent curator for that purpose as regulated in (Article 56 paragraph (3) of the Bankruptcy Act).

\section{Acknowledgements}

The author's gratitude goes to Prof. Dr. Maskuri, M.Si. as the Chancellor of the Islamic University of Malang and the Dean of the Faculty of Law of the Islamic University of Malang, who have provided motivation and strong encouragement as well as moral and material assistance to the author. The entire academic community of the Faculty of Law has provided encouraging support, whose names the author cannot mention one by one.

\section{References}

[1] Elyta Ras Ginting, 2015, Bankruptcy Law Theory of Bankruptcy, Jakarta: Sinar Grafika.

[2] Ivida Dewi Amrih Suci and Herowati Poesoko, 2016, Bankruptcy Law: Position and Rights of Separatist Creditors on Collateral for Bankrupt Debtors, Yogyakarta: LaksBang Pressindo.

[3] M. Hadi Shubhan, 2008, Bankruptcy Law: Principles, Norms, and Practices in the Judiciary, Yogyakarta: Pustaka Utama Grafiti. 
[4] Munir Fuady I, 2017, Bankruptcy Law in Theory and Practice, Bandung: Citra Aditya Bakti.

[5] II, 2003, Limited Liability Company: New Paradigma, Bandung: Citra Aditya Bakti.

[6] Peter Mahmud Marzuki, 2005, Legal Research, Jakarta: Kencana.

[7] R. Subekti and R. Tjitrosudibio, 2013, Code of Commercial Law and Bankruptcy Law, Jakarta: Balai Pustaka.

[8] 1992, Civil Code, Bandung: Pradnya Paramita Suratman and H. Phillips Dillah, 2013, Legal Research Methods, Bandung: Alfabeta.

[9] Law No. 4 of 1996 concerning Mortgage Rights for Land and Objects related to Land.

[10] Law Number 42 of 1999 concerning Fiduciary Security Law Number 37 of 2004 concerning Bankruptcy and Postponement of Debt Payment Obligations. 